\title{
75- Azizliğin ve güzelliğin trajik timsalleri: Prens Mışkin ve Nastasya Filippovna
}

\section{Güneș SÜTCÜ 1}

APA: Sütcü, G. (2021). Azizliğin ve güzelliğin trajik timsalleri: Prens Mışkin ve Nastasya Filippovna. RumeliDE Dil ve Edebiyat Araştırmalar Dergisi, (25), 1185-1197. DOI: 10.29000/rumelide.1038660.

\section{$\ddot{O} \mathbf{z}$}

On dokuzuncu yüzyıl Rus edebiyat tarihinde insanın varoluş nedeninin anlamı üzerinde felsefi düşüncelere yoğunlaşarak insanlığın geleceği konusunda derin ahlaki sorumluluğu ele alan en iyi temsilcilerden biri büyük Rus yazar Fyodor Mihayloviç Dostoyevski'dir. Slavsever geleneğin sürdürücüsü ve romantik bir ulusçu olan yazarın olgunluk dönemine ait "Budala" (İdiot, 1869) adlı romanı, evrensel sevgi kavramını ve mükemmel insan idealini yansıtması açısından önemli bir yere sahiptir. Romanda mükemmel insanı temsil eden Prens Mışkin'dir. Yazar gerek ahlaki gerek ruhsal açıdan mükemmel olarak addedilecek bir insanı betimler. Acı çekmenin ve "mecburi” kabullenişin ahlaki üstünlüğünü Prens Mışkin ile hayata geçirir. Bu nedenle romanda azizliğin trajedisini somutlaştırandır meczup Prens Mışkin. Romanın bir diğer ana kahramanı olan Nastasya Filippovna, Prens Mışkin için acının ifadesel karşılığıdır. Bu bağlamda Dostoyevski’nin Mışkin’e yüklediği görevin daha anlaşılır kılınmasını sağlayan başlıca özne konumundaki Nastasya "güzelliğin trajik" timsali olarak karşımızda belirir. Çalışmamızda "Budala” romanını seçmemizin nedeni, yazarın sanatı ve felsefesi için anahtar niteliğindeki düşüncelerinin çok yönlü olarak incelenebilmesine imkân vermesidir. Çalışmamızın özgün yanını Prens Mışkin ve Nastasya Filippovna karakterlerinin karşılaştırılması bağlamında Dostoyevski’nin ideal insan ve güzellik anlayışının özünü vermek oluşturur. Çalışmanın sonucunda Prens Mışkin özelinde bir türlü anlaşllamayan ve toplumdan kopuk yaşamayı seçenlerin hakikati arayış yolunda deli ya da budala olarak addedilmesinin ve acının tetikleyicisi olan güzellikteki Nastasya Filippovna'nın özü sunulmaya çalışılmıştır.

Anahtar kelimeler: Budala, Dostoyevski, güzellik, mükemmel insan, Nastasya Filippovna, Prens Mışkin, Rus edebiyatı

\section{Tragic images of saintliness and beauty: Prince Myshkin and Nastasya Filippovna}

\begin{abstract}
One of the best representatives of the nineteenth century Russian literature who focused on philosophical reflections on the reason for human existence and dealt with the deep moral responsibility for the future of humanity is the great Russian writer Fyodor Mikhailovich Dostoyevsky. The continuation of the Slavic tradition and a romantic nationalist, the author's novel "Idiot" (Idiot, 1869) belonging to his maturity period is very important in terms of reflecting the concept of universal love and the ideal of the perfect human being. Prince Myshkin is the representative of the perfect human in the novel. The author describes a person who would be considered perfect both morally and spiritually. He realizes the moral superiority of suffering and "compulsory" acceptance with Prince Myshkin. For this reason, she embodies the tragedy of
\end{abstract}

Öğr. Gör. Dr., Anadolu Üniversitesi, Edebiyat Fakültesi, Rus Dili ve Edebiyatı Bölümü (Eskişehir, Türkiye), gunessutcu@anadolu.edu.tr, ORCID ID: 00oo-0001-9496-4051 [Araştırma makalesi, Makale kayıt tarihi: 31.10.2021kabul tarihi: 20.12.2021; DOI: 10.29000/rumelide.103866o] 
sainthood in the novel. Another main heroine of the novel, Nastasya Filippovna, is the equivalent of pain for Prince Myshkin. In this context, Nastasya, who is the main subject that makes the task that Dostoevsky assigned to Myshkin more understandable, appears before us as the "tragic symbol of beauty." The reason why we chose the novel "Idiot" in our study is that it allows the author's thoughts, which are key for his art and philosophy, to be examined in a multi-faceted manner. The element that constitutes the original aspect of our study is to give the essence of Dostoevsky's understanding of ideal human and beauty in the context of the comparison of the characters of Prince Myshkin and Nastasya Filippovna. Nastasya Filippovna's self has been tried to be presented.

Keywords: Idiot, Dostoevsky, beauty, perfect man, Nastasya Filippovna, Prince Myshkin, Russian literature

\section{Giriş}

Büyük Rus yazar Fyodor Mihayloviç Dosyoyevski² (1821-1881) yalnızca Rus edebiyatının değil, dünya edebiyatının en önemli temsilcilerinden biridir. İçinde bulunduğu Rus toplumundan hareketle insanlığın yazgısını anlamlandırmaya çalışan yazar, savunduklarıyla varoluş̧̧u düşüncenin öncüsü kabul edilir. Çok sayıda düşünürü etkileyen Dostoyevski, insan benliğinin derinliklerindeki gizleri çözümlemeye çalışan psikolojik ve felsefi yönü ağır basan bir yazardır. On dokuzuncu yüzyll Rusya'sının modern ve büyük kentlerindeki yaşamın beraberinde getirdiği akıl karmaşasını inceleyen Dostoyevski, insanı ruhsal deneylerle sınar. Dostoyevski'nin romanlarının ana konusunu modern şehrin sıradan insanının duyumsadığı yalnızlık, umutsuzluk ve acı oluşturur. Yarattığı karakterler genel olarak içinde yaşadığı toplumsal düzenine uyum göstermeyen, kendi iç dünyasının derinliklerinde kaybolan, kendisine dayatılan kurallara biat etmeyen, bencilliğe, yoksulluğa, adaletsizliğe ve zulme karşı çlkan özellikler gösterir. Nihayetindeyse mecburi bir kabullenişi seçerek kadere teslim oluş ve Tanrı'dan af dileyiş durumu gözlenir. Aksi yönde eylemlerini sürdürenler, kendi varlığına son verme yolunu seçerler.

Dostoyevski'nin savunduğu düşünce bir Tanrı arayışı ve Tanrı'ya yakın olan insan modelini yaratma üzerine kuruludur. Yaratım gücünü insan ve yazgısına odaklayan Dostoyevski'nin romanlarının merkezinde insanın kendisi konumlandırılır. Çünkü varoluşun merkezini insan oluşturur. İnsan sorununu anlamlandırmak demek, Tanrı'nın varlı̆̆ını anlamlandırmak manasına gelir. Nitekim neredeyse tüm eserlerinde Tanrı ile zıtlaşmaya varacak kadar insanı savunmaya çalışan Dostoyevski, insanın kaderini İsa üzerinden çözümleme yoluna gider. Dostoyevski bu düşüncelerle "Budala" adlı romanında kendisi gibi sara hastası olan Prens Lev Nikolayeviç Mışkin’i ana kahramanı olarak yaratır. $\mathrm{Bu}$ bağlamda otobiyografik izler taşıyan romanda meczup ve hakikati kendi öz bilinçaltında arayan Prens Mışkin’in bir nevi Hz. İsa figürü olarak karşımıza sunulduğu anlaşılmaktadır. Mışkin için acı, hiçliğin karşısında varoluşun anlamlandırılmasıdır ve insanın Tanrıyla bir olma sürecini kapsar. Tam da bu bağlamda romanın diğer ana kahramanı Nastasya Filippovna Baraşkova, Mışkin’in yaşadığı trajedinin özsel karşılı̆̆ı olarak karşımızda belirir.

\footnotetext{
“Dostoyevski ailesinin izlerini sadece günümüz Rusya'sında değil, öncelikle Litvanya, Ukrayna ve Beyaz Rusya topraklarında sürmek gerekmektedir. Ailenin ismine yaklaşı olarak XVI. yüzylldan itibaren resmi kaynaklarda rastlanmaktadır. Çok zengin ve de ünlü bir aile olmamalarına rağmen isimleri sık sık tarihsel kişilerle birlikte anılmaktadır. (...) Ailenin Dostoyevski sseklinde adlandırılmaya başlanması Pina ve Yatsold nehirleri arasında yer alan Dostoyevo köyünün kendilerine hediye edilmesiyle ile ilişkilendirilmektedir.” Yazarın biyografisi hakkında detaylı bilgi için bkz: Kandemir, H. (2014). Dostoyevski Biyografi. Konya: Çizgi Kitabevi, 13-14.
} 
Çalışmamızda Dostoyevski'nin "Budala"3 adlı romanında mükemmel insanı temsil eden Prens Mışkin ile onun karakter çözümlemesinde önemli bir rol oynayan Nastasya Filippovna metne bağlı inceleme çerçevesinde ele alınacaktır. Çalışmanın sonunda elde edilen bilgiler ışığında kendisini her türlü suçtan sorumlu tutmayı seçen Prens Mışkin "azizliğin trajedisini” ve sadece kendini seven, özgürleşememiş Nastasya "güzelliğin trajedisini” yansıtması bakımından insan temelli çözümlemeler ortaya koymak amaçlanmaktadır. Romanı çözümlemeye geçmeden önce çözümlemenin daha anlaşlır olması amacıyla romanın konusunu özetlemekte fayda görmekteyiz.

\section{1860'ların Rus toplumunun bir aynası olarak "Budala"}

Dostoyevski'nin "Budala" adlı romanı4, en büyük aşk romanlarından biri olarak kabul edilmektedir. Romanda Prens Mışkin'e âşık olan iki kadın söz konusudur. Bunlardan biri General Yepançin’in küçük kızı Aglaya'dır. Bir diğeri ise zengin bir tüccarın terk edilmiş sevgilisi Nastasya Filippovna'dır. Bu bağlamda romanda bölünmüş bir aşkın varlığı dikkat çeker. Prensin âşık olduğu kadın güzel ve sevimli Aglaya'dır. Bölünmüşlüğün izlerini taşıdığı için Mışkin’in aşkı trajiktir. Mışkin kişilik olarak evliliğe ve cinsel arzulara çok uzak durduğu için her iki kadınla da sağlıklı bir ilişki içine giremez. Acı çekmesinin nedeni de budur. Tutkusu tam anlamıla can bulamayacağı için ruhunda acıma duygusunu hisseder. Yalnızca içinde duyduğu acıma duygusundan dolayı Nastasya ile evlenme kararı alır. Böyle bir kararı almasında toplumun ahlaksız olarak addettiği Nastasya'nın kendisini kötü hissetmesine engel olma ve onu kurtarma isteği etkili olur. Nastasya, Prens Mışkin’in kendisine gösterdiği bu kurtarıcı yaklaşım karşısında kendisinin ona iyi gelmeyeceğini ve uygun olmadığını düşünmesinden dolayı kendisine uzatılan eli tutmayı ilk önce reddeder. Bunun nedeni Nastasya'nın sırf Mışkin mutlu olabilsin diye aradan çekilmek ve onu Aglaya ile evlenmeye ikna etmek istemesiyle ilgilidir. Bir gün Aglaya, konuşmak için gittiği Nastasya Filippovna'nın evinde ona kasıtlı olarak hakaret eder ve bir anda her şey karışır. Nastasya artık rakibi için kendisini feda etmekten vazgeçer. Bunun üzerine Prens Mışkin'in kendisi için mahvolmasını istemediğinden evlenme teklifini kabul eder ancak düğün günü âşık olduğu Rogojin'e kaçar. Giderek kontrolünü kaybeden Nastasya Filippovna yüzünden iki adam da büyük acılar çekmek zorunda kalır. Romanın sonunda ise kendisini teslim ettiği bu adam tarafından öldürülür. Rogojin tutuklanarak Sibirya'ya sürülür, bu durumu önceden sezdiği için soğukkanlılıkla karşlayan ve şaşırmayan Prens Mışkin geldiği hastaneye aklını tamamen yitirmiş olarak geri döner (Köksal, 2017: 5152). Konusunu kısaca aktarmaya çalıştı̆̆ımız romanı, şimdi de metne bağlı inceleme yöntemi çerçevesinde daha ayrıntılı bir biçimde çözümlemeye çalışacağız. Günay (2003: 55) metnin betimlenmesini "daha sonra yapılacak çözümlemenin ve yorumlamanın üzerine kurulacağı, hareket noktasını oluşturacağı sağlam bir temel elde etmek için metin genelinde nesnel olarak bazı gözlemlerde bulunmak" olarak tanımlar. Bununla beraber yapacağımız çözümlemeler romanı tüm ayrıntılarıyla değerlendiren bir çalışma olmamakla beraber, romanın ana erkek ve kadın kahramanı Dostoyevski'nin estetik ve ahlak anlayışına göre tanıtmaya yönelik bir çalışma ortaya koymak amaçlanmaktadır.

\footnotetext{
3 "Eserin adının Budala olması yazarın mükemmel olumlu kahraman ideali çerçevesinden bakıldığında çelişkili görünmektedir. Rus araştırmacı İrina Kirillova, Dostoyevski’nin eserini Budala anlamına gelen idiot olarak adlandırmasının ikili bir anlam ifade ettiğini belirtir. Öncelikle bu adlandırma kahramanın deliliğine ironik bir gönderme yapar. İkinci olarak bu adlandırma kahramanın özgünlüğüne vurgu yapar. Yunanca bir sözcük olan idiot farklı özgün anlamlarına gelir.” Bkz: (Aktaran Karataş, 2018: 275).

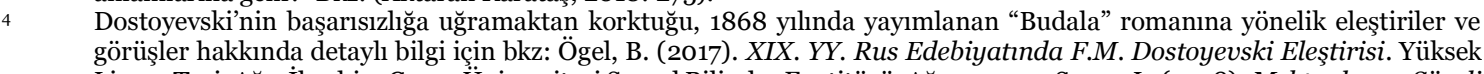
Lisans Tezi. Ağrı İbrahim Çeçen Üniversitesi Sosyal Bilimler Enstitüsü, Ağrı, 35-47.; Şener, L. (2018). Mektuplar ve Süreli Yayınlarda F. Dostoyevski”nin "Budala” Roman Hakkında Yer Alan Görüşler (1868-1881). 1. Uluslararası Eğitim ve Sosyal Bilimlerde Yeni Ufuklar Kongresi (ICES-2018), 143-150.
} 


\title{
3. Dostoyevski’nin “mükemmel insanı”: Prens Mışkin
}

Dostoyevski devrimci demokrat düşünürlerin idealize ettiği "yeni insan” tipine karşı çıktı̆̆ını ifade etmek amacıyla "Budala" adlı romanını kaleme alır. "Budala" ilk olarak Russkiy Vestnik adlı dergide yayımlanır. Roman içerik bakımından 1860'ların önemli siyasi, toplumsal ve felsefi tartışmalarını yansitıyor görünse de yazarın üstlendiği vazife daha üst mertebede olduğu anlaşılmaktadır. Dostoyevski bu romanıyla yalnızca somut-tarihsel sorunları ele almakla kalmaz, aynı zamanda insanlığın gelişim sürecindeki sonsuz amaçlarına işaret eder. Romanda ilk göze çarpan "toplumsal ve bireysel yozlaşma" temasıdır. Ancak yazar yeni eserine dair asıl niyetini 1868 yılında yeğeni Sofya Aleksandrovna İvanovna’ya yazdı̆̆g mektubunda şu sözlerle ifade eder:

"Romanın ana fikri oldukça eski ve benim çok sevdiğim bir düşünce, ama şu vakte değin de ele almaya korktuğum kadar zor bir fikir, ama şimdi bu konuyu incelemeye karar vermişsem bunun nedeni kesinlikle umutsuzluk içinde olmamdir. Romanın ana düşüncesi tam anlamıla mükemmel insanı yansitmaktır" (Dostoyevski, 2014: 144).

Dostoyevski, yeğeni İvanovna ile sık sık mektuplaşmanın yanı sıra arkadaşı Maykovski ile de fikirlerini paylaşır. Friedlander bir sonraki mektubunda romanının ana kahramanı Prens Mışkin hakkında şu satırları yazdığına dikkat çeker:

\begin{abstract}
"Romanımin ana fikirlerini çok önceden beri belleğimde tutuyorum. Onlar hem en sevdiğim fikirlerim hem de en zor olanlarıdır. Bu yüzden uzun zamandır, bu fikirlerimi arka plana koymuştum. Ana fikrim, olumlu-güzel bir insanı yaratmakta yatıyor. Bu kadar zor bir iş olamaz. Özellikle bu günlerde. Olumlu-güzel bir karakteri yaratmaya kalkışan bildiğim tüm yazarlar (Avrupa yazarları dâhil) sonuçta bu işten vazgeçtiler. Çünkü "güzellik - bir hayaldir, idealdir." Hem bizim toplumuz için hem de gelişmiş Avrupa için ulaşmaya çahş̧tı̆ımız "ideal" henüz belirlenmemiştir" (aktaran Purevdorj, 2017: 71).
\end{abstract}

Dostoyevski'nin yarattığı mükemmel insanının en karakteristik özelliği, tüm insanlara sonsuz sevgi, saygı ve merhamet duygusu beslemesidir. Kendi öz değerinin farkındalığını yaşayamayan, çevresindeki herkese yalnızca insan olduğu için değer veren, dünyevi hırslardan bütünüyle arınmış, her daim dürüstlüğü savunan mükemmel insanı tanımlayan yanlarıdır (Sarıbaş, 2010: 60-61). Mışkin en yüksek düzeyde konumlandırılan seçilmiş ve özel insanlar arasındadır. Herhangi bir grubu temsil etmez ve eşsizdir. Rus edebiyat uzmanı Lidiya Lotman çalışmasında "Mışkin'in tekliği, eşsizliği onu İsa ile özdeşleştirir” (aktaran Karataş, 2018: 275) diyerek Dostoyevski'nin Mışkin ile Hz. İsa arasında gerçek bir bağ yaratmayı amaçladığını gösterir. Çünkü yazara göre "dünya üzerinde gerçek anlamıyla mükemmel tek bir insan mevcuttur. O da Hz. İsa” dır (Dostoyevski, 2014: 144). Yazar romanında mükemmel bir insan yaratmaya çalışır ve ana kahramanına "Prens İsa" diye seslenir. Prens Mışkin’i hem edebiyat ve sanat çerçevesinde hem de o dönemin felsefi ve tarihi bilimlerine uygun yaratmaya çalışır. Tarihçi Friedlander ve Hrapçenko'ya göre Dostoyevski Prens Mışkin’i yaratırken özellikle 1863’te Fransız yazar, felsefeci ve tarihçi E. Renan'ın yazdığı “İsa'nın Hayatı” kitabından etkilenir (aktaran Purevdorj, 2017: 80). Bu noktada araştırmacıların bir kısmının Mışkin’in mükemmel, olumlu insan idealini timsalleştirdiğini ve Prens İsa'nın trajik gelişen olayların bir kurbanı olarak kabul ettikleri gözlenir. Diğer bir kısım ise erkek kahramanın ilişkisel kaderini “yüce düşüncelerin başarısızlığı” olarak düşünür (Toiçkina, 2001: 206). Dolayısıyla Prens Mışkin’e yönelik yapılan değerlendirmelerin çok çeşitli olduğu ve onu çok yönlü değerlendirmenin daha uygun olacă̆ı yargısında bulunulabilir.

Prens Mışkin kendisine yapılan kötülüklere iyilikle karşllık vermesi, bütünüyle saf bir bilince ve kalbe sahip olması, çevresindekilerin aksine dünyevi nimetlerden ve hırslardan arınmış olması, insanları her koşulda sevmeyi seçmesi, yoksulların ve günahkarların dostu olmasından dolayı Hz. İsa ile 
özdeşleştirilir. Prens Mışkin imgesinin İsa ile özdeşleştirilmesine yönelik incelemelerde bulunan araştırmacılar arasında İ. A. Bityugov, İ. Burdin, G. G. Yermilov, R. G. Nazirov, A. Ye. Kunilskiy gibi isimler yer alır. Buna karşılık L. Myuller, G. K. Şennikov ve L. Levin gibi araştırmacılar bahsi geçen durumun geçerliliğine dair şüpheli yaklaşırlar. Bu bağlamda Dostoyevski'nin bizzat kendisinin romanın el yazmalarında "Prens İsa" başlığı altında yazdığı bölüme dikkat etmek esasen Mışkin'in İsa ile özdeşleştirildiğini kanıtlar niteliktedir (Şetinin, 2007: 26). Mışkin’in bahsi geçen özelliklerinin vurgulanması amacıyla romanda ilk olarak beyaz rengin yoğun bir şekilde kullanılması dikkat çeker. İnsani arzulara karşı istemsiz kalmayı seçen Mışkin’in yabancılığını beyaz, ömrünü Nastasya Filippovna'ya adayan Rogojin'in ise siyah rengi ifade etmesi (Karataş, 2018: 281-282) aralarındaki karşıtlı̆̆ın keskinliğini göstermektedir.

Dostoyevski'nin eserlerinde insanların iyi ya da kötüyü seçmelerinin sonucunda yaşananlar aslında Tanrı inancının bağlantısal düzlemiyle şekillenmektedir (Şahin, 2016: 61-62). Prens Mışkin tüm benliğinde müthiş bir acı çekmesine karşın, insanlara olan sevgisini, inancını kaybetmemesi bakımından bir nevi Hz. İsa figürüdür: “...Hatta Mışkin’in fiziki betimlenişi bile, Ortodoks ikonlarındaki İsa'dan esinlenilmiş gibi görünmektedir: Ortadan biraz uzun, iyice sarışın, gür saçlı, çökük avurtlu ve ufak, sivri, nerede ise bütünüyle beyaz sakallı" (Dostoyevski, 2001: 198). Her koşulda iyi bir insan kalabilmeyi başaran mükemmel insanı Prens Mışkin ile kişileştiren Dostoyevski, rasyonel egoizme karşı çıkışını ifade eder.

Mışkin’in duyumsadığı acıların nedeni toplumsal değil, benliğini kasıp kavuran adaletsizlikten ötürüdür. Nihayetinde eşitsizlik, adaletsizlik, haksızlık gibi durumlarla mücadele etmeye çalışan insan bir zaman sonra güçsüz düşer. Bu noktada yalnızca mevcut durumu kabule geçip acı içinde huzuru bulmaya çalışmaktır bireysel olarak yapabileceği. Bu nedenledir ki Friedlander'e göre Dostoyevski acıların kökten ortadan kaldırılamayacağı bilinciyle insanlığın yapması gerekeni sevgiden ve hoşgörüden yana taraf tutup acıları paylaşmak olarak görür (aktaran Karataş, 2018: 288-289). Bahsi geçen yaklaşım yazarın Ortodoks inancının "herkesi sevgiyle kucaklama” öğretisini (Kartal, 2015: 177) benimsemiş olmasılyla ilgilidir.

Araştırmacı Vasiliy İvanov "Bizim Büyük Umudumuz Ya Da Dostoyevski'de "Rus Düşüncesinin" Kadınsılığı” (Ogromnaya naşa nadejda ili jenstvennost "russkoy idei” u Dostoyevskogo") adlı makalesinde şöyle yazar: "Dostoyevski'nin sanatında ve dünya görüşünde Hristiyan sevgisinin kalbi olan İsa imgesi merkezi bir yere sahiptir. Ancak İsa sevgisi bir fedakârlık değil, kendini feda etmedir (Kopılova \& Buryanova, 2021: 50). Öyle ki Dostoyevski'nin kendisi romanın ilk yazmalarında "acı çekme, Hristiyanlığın tümüdür” (aktaran Battalova, 2011: 32) ifadesini kullanır. Mışkin de yazar gibi hisseder ve bu düşünceyle hareket eder. Bu noktada hiç şüphesiz Hristiyanlığın tek bir noktaya indirgenmesi söz konusu olamaz. Mışkin, Nastasya'yı ne ruhen ne de toplumsal açıdan "diriltemez." Kötülüklerle bezendirilmiş dünyada mükemmel insan Mışkin dahi kendi gücüyle başka bir insanı kurtaramaz, Tanrı'nın varlığı duyumsanmadan şeytanın karşısında durulamaz (Bogdanova, 2007: 103). Bununla birlikte romanda Tanrı'nın varlığı doğrudan hissedilmez. Ana kahramanlardan hiçbiri ne dua eder ne kiliseyi ziyaret eder ne de İncil’i okur. Dolayısıyla da romanda ruhani bir kişilikten bahsedilemez.

Prens Mışkin'de yalnızca İsa'ya değil, aynı zamanda Don Kişot'a ait özellikler de bulunmaktadır. Bu bağlamda Don Kişot özellikleri yazara Mışkin’in kişilik bakımından mükemmelliğini ortaya çıkarmasına ve içsel mücadelesinde çektiği acı sayesinde kurtulma düşüncesine, toplumun manevi durumunu değiştirme girişimlerinin gerçek olmayacağını göstermeye imkân verir (Akimova, 2021: 45). Prens Mışkin imgesini farklı çerçevelerde değerlendiren araştırmacılar da bulunmaktadır. Yunan Tanrısı 
Apollon'un lakaplarından biri olan "tarla faresi”nin karanlıkta görebilme özelliğini “Tanrı'yı her durumda görebilmesinin” bir sembolü olarak görenlerden bahsedilebilir (Şetinin, 2007: 27). Bu noktada soy isminden dolayı Mışkin’in Apollon ile ilişkilendirildiği de görülür. Sovyet araştırmacı Galina Kurliyandskaya’ya göre ise Mışkin, literatürde "trajik karakter" olarak tanımlanır. Böyle bir tanımlama yapmasını Dostoyevski'nin toplumsal idealini gerçekleştirme fikriyle ilişkilendirir (Karataş, 2018: 291292). Dostoyevski’nin Prens Mışkin’i gerçek insanların otobiyografilerinden aldığından da bahsedilmektedir. Buna göre yazar Russkoye Slovo adlı derginin sahibi Kont G.A. Kuşelyov ve Bezborodko'nun hayatından esinlenerek Prens Mışkin ile Nastasya Filippovna'nın ilişkisini konu eder (aktaran Purevdorj, 2017: 71-72). Ukraynalı edebiyat eleştirmeni K. V. Moçulskiy "Prens, Dostoyevski'nin sanatsal bir oto portresidir, onun hayat öyküsü yazarın iç dünyasının biyografisidir" diyerek Mışkin'in otobiyografik bağlamda ele alınması gerektiğine işaret eder. Benzer düşünceyi savunan bir başka isim Rus filozof ve edebiyat eleştirmeni V. V. Rozanov "yazarın eserlerinin her birinin özünde bizzat kendisinin deneyimlediği hem yüceltici hem de alçaltıcı durumlar söz konusudur. Buradaki dış değil, iç gözlemdir” (Battalova, 2011: 31). Bu değerlendirmeler romanın anlamlandırılmasına yönelik yazar ile kahraman arasındaki bağı mercek altına almaya sevk eder bizi. Söz konusu durum Henry Troyat'a göre kitapta şu şekilde okunabilmektedir:

"Prens Mışkin sara hastasıdır. Dostoyevski gibi o da nöbetten önceki büyük sevinci duyuyor. Onun gibi o da bir şimşek parıltısı içinde; dünyanın en üstün uyumunu açı̆̆a vuran çok değerli dakikayı bekliyor, ona umut bağlıyor: "Bu dakikada, havarinin olağanüstü sözcüklerini anlyorum gibi geliyor bana: Zaman var olmayacak artık!” (Troyat, 200o: 367).

"Niyetim bütünüyle güzel bir insanı anlatmaktır" sözlerini sarf eden Dostoyevski’nin kendisinden izler taşıdığını gözlemlediğimiz Prens Mışkin karakteri, içinde yalnızca saf duygular barındıran, sara hastası ve küçük yaşta öksüz kalan duygusal bir gençtir. Uzun yıllar hastalı̆̆ın pençesinden kurtulma mücadelesi verir ve tedavi için İsviçre'ye gönderilir. Ancak kendisine gelen mektupla tedavi masraflarının daha fazla karşılanamayacağını öğrenmesi üzerine Petersburg'a geri dönmek zorunda kalır. Sergilediği tavırlar nedeniyle çevresindekiler tarafından kabul görmez. Kendisini tam anlamıyla ifade edememesi ve toplumsal normlara çok hâkim olamamasından dolayı içinde yaşadı̆̆ı çevreye bir türlü uyum sağlayamaz. Yirmi yedi yaşında ${ }^{5}$ olmasına karşın halen bir çocuk edasıyla hareket ettiği ve fiziksel olarak da olgun bir görünüme sahip olmadığı görülür. Sağlı̆̆ına iyi geleceği düşüncesiyle uzun yllar İsviçre'de bir köyde yaşar. İnsanlardan izole kalarak geçirdiği zamanlar bir nevi ruhsal tedavi süreci niteliğindedir. $\mathrm{Bu}$ anlamda tıpkı Dostoyevski'nin diğer romanlarında olduğu gibi yeraltı trajedisinin bu seçimle gerçekleştirildiği gözlenir. Ancak insanlardan uzun süre uzakta kalmaktan ruhsal olarak bitkin düşen Prens Mışkin, yeniden cam kırıklarıyla çevrelenmiş insanların dünyasına dâhil olmaya karar verir. Sara nöbetlerinin sık sık tekrar etmesinden dolayı adeta bir budalaya dönüştüğünü ve bu dönemlerde bir budala olduğunu kabullenen Mışkin, esasen kendisinin akıllı oluşunun insanlar tarafından fark edilmediğini ve çevresindekiler tarafından halen bir budala olarak görüldüğünü ifade eder (Sarıbaş, 2010: 61-62). Buna karşllık hiçbir şekilde onlara karşı kin ve öfke duymaz.

Prens Mışkin gösterdiği davranışsal ve düşünsel özelliklerle içinde bulunduğu dünyaya ait olmayan, acı çekişin ve boyun eğişin getirdiği ahlaki üstünlüğün timsalidir. Fiziksel olarak fazlasıyla zayıf olarak resmedilir ve daha sonrasında, tıpkı Dostoyevski’nin diğer romanlarında olduğu gibi, ruhsal olarak güçlenmesiyle karşımıza çıkar. Öyle ki hakikat arayışında en fazla sara nöbetleri anında sarsıcı düşünsel aydınlanmalar yaşar. Bu anlarda hayata olan bağlllığının, kendini algılama düzeyinin kademeli olarak

“Dostoyevski’nin eserlerinde otobiyografik izler görebilmek mümkündür. Bu bağlamda Prens Mişkin’in yirmi yedi yaşında olması ve İsviç sohbette 27 yaşındaki genç bir adamın idama mâhkum edilişinin ve son anda idamdan kurtuluşunun hikâyesini anlatmaktadır. Yazar burada aynı şekilde ana karakter aracılığıyla aslında kendi yaşantısını aktarmaktadır." Bkz: Ögel, a.g.e., 2017: 36-37. 
arttığını fark eder. Zihnen ve kalben ışığa boğularak duyumsadığı tüm endişelerden arındığını, yalnızca dinginlik ve huzur veren duygularla dolduğunu belirtir.

Romanda Petersburg toplumunun hayatını iyileştirmeye yönelik hareket eden Prens Mışkin’in hayatında gözlenen değişiklikler, anlatıcı ve çevresinin anlatımıyla okuyucuya yansıtılmaktadır. Romanın birinci bölümünde diğer karakterlerin Mışkin'e yönelik değerlendirmelerine bakıldığında ilk baştaki olumsuz intibaının sonrasında olumluya çevrildiği anlaşılmaktadır. Prens Mışkin bir anda tamamen değişkenlik gösteren davranışlar sergiler. Herkesin budalaca tavırlarda bulunduğunu düşündükleri anda dünyanın en akıllı insanı gibi davranmaya başlar. Onu yakinen tanıan çevresindekiler zamanla onun ne kadar akıllı olduğunu idrak ederler. Göstermiş olduğu iyi niyetinden dolayı çevresindeki herkes ona hayranlık besler hale gelir. Nitekim Prensi karalamak amacıyla asılsız haberler yayımlayan Keller dahi Prens hakkındaki düşüncelerini şu sözlerle ifade eder:

\begin{abstract}
“...Ama şimdi kendi gözleriyle görüyordu ki, bizim topumuzdan en az on kat daha asil düşünmüş, asil bir karar vermişti Prens! Çünkü onun aradığı zenginlik, ışıltı, şan, şeref değil, yalnızca gerçekti! Yükseklerdeki insanların gönül aksşlarının ne yana olduğu malum, Prens ise aldiğı eğitim öğretim açısından yükseklerdeki insanlardan olamayacak kadar yüksek biriydi...” (Dostoyevski, 20o8: 671).
\end{abstract}

Prens Mışkin’in monologları da yazarın benimsemiş olduğu değerler sistematiğini yansıtması bakımından önemlidir. Romanın birinci bölümünde Mışkin’in olumlu yanları vurgulanırken ikinci ve üçüncü bölümlerde olumlu yanlarının çok yönlü olduğuna dikkat çekilerek daha güçlü kılındığı görülür. Yazar böylelikle eşzamanlı olarak iki hakikati nesnel bir şekilde aktarır. Prens Mışkin’in insana olan inancını ve insana dair benimsediği düşünsel hakikati belirli bir seçim çerçevesinde okuyucuya sunar. Prens Mışkin normal bir insanın arzuladıklarına karşı istemsizdir. Yaşadığı toplumda böylesine sevecen kalabilmeyi başarır ancak öte yandan insanlarla iletişim kurmada güçlük çeker. Yalnızca çocuklarla samimi dostluk kurabilir. Nitekim çocuklarla kurulan iletişim aracıllğılyla vicdan öğretisi sunulur. Samimiliği, açık sözlülüğü, saf kalpliliği, sadeliği bakımından çocuksu özellikler taşıması onun budala olarak tanınmasına neden olur. Yazara göre ise çocukların dünyasıdır dünyanın en hakiki değerlerinin gözlenebildiği yer (Toiçkina, 2001: 209-218). Bir çocuktan dahi daha saf bir kalbe ve zihne sahiptir Prens Mışkin. Bu durumun farkındalı̆̆ını yansıtan şu sözleri sarf eder:

"Asıl çocuk olan benmişim, bu, başlangıçta bir kuşkuymuş, ama giderek tam bir inanç halini almış onda. Benim yalnızca boyum posum, elim yüzüm bir yetişkine benziyormuş; ama gelişme yönünden, ruh, kişilik yönünden hatta belki akıl yönünden bile bir çocukmuşum ve altmış yaşıma dek de yaşasam, böyle kalacakmışım” (Dostoyevski, 2018: 110).

Alıntıda da bahsedildiği gibi, romanda Prens Mışkin’in her daim sevgi odaklı olduğu ve bir insanı kurtarma hayat felsefesine sonuna kadar sadık kaldığı görülmektedir. Öte yandan Mışkin’in kendisini her türlü suçtan sorumlu tutması, Dostoyevski’nin onu tüm insanlığın acılarına dâhil etmesinden ileri gelir. Oysaki esasen özgür olan odur. Çünkü çevresindeki tüm insanlar, dünyevi hırsların ve arzuların kölesi haline gelmiştir. Bu bağlamda yazar romanda iki gruba ayrılan insanları "dar kafalılar" ve "kafası daha çok çalışanlar" çerçevesinde inceler. Yazara göre dar kafalı insanlar kibirli, kendini çevresindekilerden daha akıllı gören, bitmek bilmeyen arzuların kölesi olan, hesaplar peşinde koşan, maddi değerleri öncelikli gören, vermekten daha çok almanın daha iyi olduğunu düşünenlerdir. Paralarının olmayışından utanan bu insanlar, çoğu zaman hayatlarını garanti altına alabilmek amacıyla maddi menfaatleri doğrultusunda hareket ederler. Her zaman çok mutlu ve huzurludurlar. Bunun nedeni dar kafalı insanların kendilerine olan yıkılmaz bir özgüvene sahip olmalarıyla ilişkilendirilebilir. Tam tersine kafası daha çok çalışanlar ise çoğu zaman mutsuz ve huzursuzlardır (Sarıbaş, 2010: 46). Dostoyevski'ye göre insanların içinde bulundukları bu yozlaşmış durumdan kurtulmalarının reçetesi 
Prens Mışkin’in ifade ettiği şekliyle "Dünyayı güzellik kurtaracaktır!” (Dostoyevski, 2008: 604) leitmotivi üzerinden okunabilmektedir.

\section{Acının "güzel" tetikleyicisi: Nastasya Filippovna Baraşkova}

Güzellik kavramı, Dostoyevski’nin estetik anlayışına göre ana imgelerden biridir. Söz konusu kavrama yönelik başlıca yaklaşımlar, Platon'un felsefesí ${ }^{6}$ üzerine temellendirilmiştir. Platon'a göre insanoğlu dünyevi hayata dair güzelliği görürken ilahi ve tanrısal güzelliği hatırlar (Tumarkina, 2019: 112). Dostoyevski’nin ahlaki arayışları dinsel arayışlarından bağımsız olarak anlamlandırılamaz. Yazarın estetik ve etik anlayışının odak noktasında İsa bulunur. Öyle ki Nastasya Filippovna’nın insanı felakete sürükleyen güzelliğinin ardında saklı olan karışık iç dünyasını ilk gören ve İsa ile özdeşleştirilen Prens Mışkin’in "Dünyayı güzellik kurtaracak” aforizmasını söylemesi romanda kilit bir göreve sahiptir. Buradaki güzellik kavramı estetik olmasının yanı sıra ahlaki yanları da bünyesinde barındırmaktadır. Dolayısıyla roman kahramanlarının ruhsal arayışları söz konusu güzellik kavramının manevi yanlarıyla da ilişkilidir (Manukyan, 2020: 753). Yazar acıyla kutsanmış manevi güzelliği, romanda birbirine benzeyen iki farklı kadın aracılığıyla yansıtmayı amaçlar. Bu anlamda resmettiği kadın kahramanlar Nastasya Filippovna ile Aglaya'dır.

Romanda iyilikten yoksun olarak resmedilen Nastasya Filippovna'nın güzelliği, yıkıcı bir etki yaratır. Güzellik teması, yazarın estetik ve ahlak anlayışını bir araya getirir (Akimova, 2021: 46). Böylelikle "Budala" romanı, Rus dini-felsefi düşüncelerin gelişimini belirleyen bir vektör niteliğindeki "Dünyayı güzellik kurtaracak" aforizmasının ilk çıkış noktası haline gelir. M. Tekin’e göre "edebiyatta özellikle roman türünde rağbet gören teknik olarak 'leitmotiv' türlü vesilelerle tekrarlanan ifade kalıbıdır" (aktaran İnan, 2005: 6). Romanda geçen bu aforizma, leitmotiv olarak karşımızda belirir. Dünyayı kurtarmak gerek ama dünyayı kurtaracak olan nedir? Dostoyevski dünyayı güzelliğin kurtaracağını düşünür. Ancak hangi güzellik ve güzellik midir kurtarıcı? (Kopılova \& Buryanova, 2021: 52). Romanda bu soru cevapsız bırakılır. "Dünyayı güzellik kurtaramaz, güzelliğin kendisi kurtarılmaya muhtaç durumdadır. Dostoyevski, Nastasya ve Aglaya'nın kaderlerinde güzelliğin çirkinleşmesine dikkat çeker" (Hafızoğlu, 1998, 19). Dostoyevski "Budala"yı yazdığı sırada "Benim için romanın sonucu en önemlisidir" ifadesinde bulunur. "Neden Rogojin Nastasya'yı kurtarmaz?” sorusunun yanıtı onun beslediği duygunun tutku olmasıyla ilgilidir. Yazarın ispatlamayı arzuladığı durum şudur: "Dünyayı güzellik kurtaramaz fakat gerçek sevgi kurtarır.” Bu nedenle Prens Mışkin’in esas amacı, Nastasya Filippovna'yı diğer bir deyişle "bitmiş bir insanı" kurtarmak olarak ifade edilir. Nastasya Filippovna'daki iyilik, hakikat ve güzelliğin yitirilen birliğini yeniden eski haline getirmek, İsviçre'den Petersburg’a dönen Prens Mışkin için mühim olarak görülür. Nastasya Filippovna romanda hakarete uğrayan ve istismar edilen "güzelliğin" timsalidir: “...yetmiş beş bin rubleyi aldıysa, bu onun hiçbir suçu olmadan kırllan genç kızlık gururunun bedeli değil, düpedüz, berbat edilmiş yaşamının karşllı̆̆lymış” (Dostoyevski, 2015: 57-58). "Güzellik güçtür” söyleminde bulunan yazar, roman boyunca dünyanın kurtuluşuna dair bir tartışma yürütmektedir (Aktaran Purevdorj, 2017: 83). Bununla birlikte Dostoyevski'nin romanlarında kadının her zaman ikinci planda olduğu görülür:

\footnotetext{
6 "Güzel kavramını felsefi ve estetik açıdan derinlemesine ilk ele alan kişi Platon olduğu gibi aynı zamanda mimesis olarak bilinen sanat kuramının kökeni de yine ona dayanır". Daha detaylı bilgi için bkz: Ülger, E. (2013). "Platon'un Sanat Kuramının Düşünsel Evrimi”. FLSF Felsefe ve Sosyal Bilimler Dergisi. 15-28.
} 
"Kadın, erkek kişiliğinin ikiye bölünmesine sebep olur. Acıma aşkı, şehvet aşkı, Prens Mışkin hem Nastasya Filippovna'yı seviyor hem de General Yepançin’in güzel kızı Aglaya'yı. Aglaya'nın güzelliği onu çekiyor. Fakat Nastasya Filippovna'nın yürekler acısı, onun yaşamına amaç katıyor. Eğer o bir erkekse, Nastasya'yı kurtarma fikri taşımaktadır: "Yüzüne dayanamıyorum, yüzünden korkuyorum. Onu aşkla değil, acımayla seviyorum” (Troyat, 200o: 365).

Yazarın romanlarındaki kadın imgeleri, güzellik temasıyla ayrılmaz bir ilişkide sunulur ve ortaya koyduğu ana fikrin anlaşılmasında önemli bir role sahiptirler. Bu konuya ilişkin olarak Rus edebiyat ve kültür tarihçisi Yu. M. Lotman genç kızların ideallerinin ve gerçek kadın biyografilerinin dâhil edildiği Rus kültüründeki kadın imgelerini üç stereotipe ayırır: 1) Şefkatle seven, hayatı ve duyguları mahvolmuş kadın imgesi 2) Erkeklerin dünyasına ilişkin tüm şartları altüst etmeye cesaret eden şeytani karakter 3) Erkeklerin manevi zayıflıkları ile kadınların kahramanlıklarının birbirine karşıt durumlar oluşturmasına neden olan “tipik edebi kahraman”. Lotman’ın bu değerlendirmesine göre Nastasya Filippovna imgesi ikinci tip bağlamda ele alınmalıdır. Karmaşık ve çok yönlü bir karakter olan Nastasya Filippovna aşağılanan güzelliğin timsalidir. Dostoyevski bu kadın karakterini romanda resmedilen portresi ve psikolojik özellikleri aracılı̆̆ıyla çözümler. Bu bağlamda iç ve dış güzelliğinin birbirine karşıt olarak verildiği gözlenir. Resmedilen portresinde gurur, acı, nefret ve savunmasızlık bir arada okunmaktadır. Ondaki insani değerleri gören yalnızca Prens Mışkin'dir. Dostoyevski el yazmalarında bu konuya ilişkin şöyle yazar: "Nastasya Filippovna, karmaşa ve güzelliktir (kader kurbanıdır)". Yazar Ye. Kurganov da kader kurbanlığını destekler nitelikte "F. M. Dostoyevski'nin 'Budala' Romanı" (Roman F. M. Dostoyevskogo "İdiot”) adlı çalışmasında Nastasya Filippovna'nın soyadı "Baraşkova”yı etimolojik açıdan7 "kurban" anlamına gelen "agnets" (агнец) sözcüğü ile ilişkilendirir. Benzer noktaya dikkat çeken V. F. Pogoreltsev Nastasya Filippovna'nın "dayanılmaz bir güzellik” olduğundan (Aktaran Petrova, 2016: 24) bahseder. Hem kendine hem çevresine acı veren bir güzelliktir o. Huzuru arayan bu güzellik, bir türlü bulamaz. "Düşmüş” bir kadın kahramanın kurban olarak ölmesi, acı aracıllğıyla onun ruhsal yanlarının temizlenmesi anlamına gelir. Nihayetinde dış güzellik, devasa bir içsel trajediyle bütünleşir.

Markist-Leninist edebiyat bilimcilerinin tarafında bulunan L. P. Grossman ile G. M. Fridlender Nastasya Filippovna'nın Hristiyan ahlakının ideallerine yönelik doğrudan bir çağrı niteliğinde olduğunu ve Dostoyevski’nin bu kadın imgesini şiirselleştirdiğini iddia ederler. Rus dilbilimci ve yazar T. A. Kasatkina'ya göre ise Nastasya Filippovna'nın isminin anlamında tanrısal bir prototip görülmektedir (aktaran Kuznetsova, 2015: 150). Rus düşünür N. A. Berdyayev de Dostoyevski'de yalnızca erkek antropolojisi bulunduğuna, Nastasya Filippovna ve Gruşenka'da ise erkeklerin kaderini felakete sürükleyen durumların gözlenmesine dikkat çeker. Öyle ki Nastasya karakterinin yaratım kaynağının antik Yunan şair Euripides'in tragedyasındaki Medeya ${ }^{8}$ olduğundan bahsedilir (Nilova, 2020: 204). Aralarındaki benzerlik çevrelerindekileri felakete sürüklemeleri ve aşk üçgeninde kalıp kendilerinin yok oluşlarına neden olmalarıdır.

Dostoyevski'yi romanda asıl ilgilendiren Mışkin ve Rogojin'in kaderi olsa da Nastasya Filippovna üzerinden kaderlerinin şekillendiği gözlenir. Bu noktada yazarın kadına olan bakışını şu sözlerinden daha iyi anlamak mümkün görünebilir:

\footnotetext{
$7 \quad$ Kahramanların isimlerinin anlam bakımından incelenmesine yönelik daha detaylı bilgi için bakınız: Sapel'nikov, A. V. (2005). İmena Geroyev romana F.M. Dostoyevskogo "İdiot". Vestnik Novgorodskogo gosudarstvennogo universiteta. No: 33. 69-72.

$8 \quad$ Medea, Euripides tarafından yazılmış, ilk MÖ 432'de sahne almış ve temeli İason ve Medea'ya dayanan bir Antik Yunan tragedyası. Oyun, İason'un eşi ve "barbar" Kolhis Krallığı'nın prensesi olan Medea'nın, İason'un onu bırakarak Korinthli Yunan bir prensesle evlenme kararı alması sonucunda attı̆̆ı adımları konu alır. Detaylı bilgi için bkz: Euripides. (2014). Medea. (Çev. Ari Çokona) Türkiye İş Bankası Kültür Yayınları.
} 
"Dostoyevski'ye göre kadın, ancak bir tepki yaratıcısıdır. Kadın, erkeği acıya uyandırmak için, ona işkence etmek için, onu yıkmak için, onu yükseltmek için, onu ahlaksal yasalarının dışına çekmek için, onu toy, şaşkın bir durumda, soluk soluğa, özgürlüğün sözle anlatılamaz dünyasma atmak için vardır. Son yatışıklğı haber veren iç kışkırtısını temsil eder o" (Troyat, 2000: 364-365).

Buna karşılık Prens Mışkin Nastasya Filippovna’nın güzelliğini ilk gördüğünde iyiliğin kurtarıcı gücünden faydalanmak istemiştir ve güzelliğinden fazlasıyla etkilendiği şu satırlardan okunabilir:

"Nastasya Filippovna bu demek?” diye murldand ve hemen heyecanla ekledi: "İnanulmaz bir güzellik!" Portredeki gerçekten olağanüstü güzel bir kadınd. Üzerinde son derece sade, şık, siyah ipek bir giysiyle fotoğraf çektirmişti. Besbelli koyu kumral olan saçlar evdeymiş gibi güzelce toplanmıştı. Derin bakışlı gözleri koyu renk, alnı düşünceliydi. Yüz ifadesi tutkulu, sanki mağrurdu. Yüzü hafif zayıf, belki de soluktu...” (Dostoyevski, 2015: 35).

Etkileyici güzelliğinin yanı sıra Nastasya Filippovna son derece gururlu ve onurlu bir kişiliğe de sahiptir. Gurur, kibir, dünyevi adaletsizliğe isyan duyma onun temel kişisel özellikleridir. Prens Mışkin’in kendisine acımasına tahammül edemez ve gerçekten sevilmesine engel olan karanlık geçmişinden kopmay bir türlü başaramaz. Aslında çevresindeki herkes onun namuslu bir kadın olduğunu ve yaşadığı çarpık duruma sevgilisi Totskiy’nin neden olduğunu bilir. Ancak yine de hiç kimse onu "düşmüş kadın" olarak yaftalamaktan geri kalmaz. Prens Mışkin, ondaki gururu ve ruhen çektiği acıları gözlerinden hemen fark eder. Mışkin için acının ifadesel karşılığıdır Nastasya Filippovna:

"İnsanın ruhunu yücelten bir acının ucuz bir mutluluktan daha değerli olduğunu ve acı çekmenin büyük bilinçler ve derin yürekler için her zaman zorunlu olduğunu savunan Dostoyevskïnin günahkârlara, suçlulara ve katillere olan ilgisi Hristiyanhğın kendini feda etme temelli sevgi kavramı ve bağışlayıcılı̆̆ıla yakından ilgilidir ve onun dini sorgulamalarını yansıtmaktadır" (Şahin, 2016: 86).

Nastasya Filippovna da Mışkin’in kendisine duyduğu acımanın farkındadır. Mışkin'e göre Nastasya mahvedici bir cehennemin içinden safihane bir şekilde çıkmış ve bu nedenle de onun yanında olmasından onur duyacaktır: "Siz beni onurlandıracaksınız ben sizi değil. Ben bir hiçim. Siz ise acı çekmiş ve korkunç bir cehennemden tertemiz çıkmış birisiniz; bu az bir şey değildir” (Dostoyevski, 2008: 212) diyerek Mışkin acının derinliklerinde barınan masumiyetin kutsallığına dikkat çeker.

Prens Mışkin için Nastasya Filippovna en başından itibaren olası idealin timsalidir. Nastasya'nın güzelliği birbirine zıtlık gösteren "gurur ve acı" üzerinden aktarılır. Mışkin'e göre bu zıtlıkla uzlaşmak yalnızca iyiliğe başvurulmasıyla mümkün kılınabilir (Kuznetsova, 2015: 152). Mışkin için acı, güzelliğin ayrılmaz bir niteliğidir. Bu noktada Dostoyevski’ye göre acı çekme kavramının üzerinde etraflıca düşünülmesi gereken konuların başında geldiğine değinmek gerekmektedir. Çünkü yazar mutluluğa ve tam inanca doğru gidilen yolda acı çekmenin gerekli olduğu inancını taşır. İnsanın çektiği acılar sayesinde manevi bir dönüşüm yaşayabileceği ve kendi hür iradesiyle duyumsadığı acılara rağmen nihai kurtuluşa varabilmesi için ilk koşul insanın inançlı olmayı seçmesidir. Dostoyevski’nin Tanrı, İsa ve günah kavramlarına ilişkin düşünceleri benimsediği Hristiyanlık öğretileriyle uyumluluk gösterir. Buna karşılık "İnsanlar günahları için mi acı çekmektedir yoksa İsa tüm insanlık adına yeterince acı çekmiş midir?” sorusu romanın sonunda netliğe kavuşturulmaz. Dostoyevski için acı çekme, bir nevi insanın arınmasını ve yenilenmesini sağlar (Şahin, 2016: 86). Benzer şekilde İngiliz tarihçi Edward H. Carr’a göre ilkel Hristiyanlığın acı çekmeyi kutsal gören öğretisinin etkileri Dostoyevski'de geniş bir şekilde yer bulur (aktaran Şahin, 2016: 86). Dostoyevski'ye göre insanı dönüştüren çektiği acılardır. Hakikati bulmanın özü acı çekmekten geçer.

Romanda Nastasya Filippovna'nın hayatının trajik bir sonla biteceği esasen ilk baştan bellidir: 
"Kiliseye giderken; "Bir ölü gibi solgunum" diyor. Bu günahkâr ruhun, kurtuluşu tek ölümde midir sorusu okuru meraklandırabilir. Nastasya Filippovna, bir hayvanın, bir diğer hayvan tarafindan kokusuyla çekildiğini hissetmesi gibi seviyor Rogojin’i. Rogojin’i sevmekle birlikte onun kendine yaraşır olmadığını da bilir. Sadece Prens Mışkin’in onu alçalmadan kurtarabileceğine inanır. Fakat Prens Mişkin'in aşkı, onu memnun etmek ereğini güttüğünden actmaya çok yakındır” (Troyat, 2000: 370).

Böylelikle güzelliğin trajik timsali olarak addedebileceğimiz Nastasya Filippovna’nın "hastalanmış" toplumda nefes alamayacak durumda oluşunun romanın sonunda kurban olmasıyla somutlaştırıldığı görülmektedir.

\section{Sonuç}

Dostoyevski'nin kendisi gibi sara hastası olan Mışkin’i yaratırken İsa’yı düşünerek hareket ettiği, ancak burada timsalleştirilenin Ortodoks kilisesindekinden farklı olarak "mükemmel insan"ı sembolize eden İsa olduğu farklı görüşlerin sunulmasıyla vurgulanmıştır. Bu noktada Prens Mışkin'e yönelik yapılan değerlendirmelerin çok çeşitli olduğu ve onu tek yönlü değerlendirmenin mümkün olmayacağı yargısına varılmıştır. Aynı zamanda yazarın içe bakış yöntemi aracılığıyla Mışkin’in karakter çözümlemesini gerçekleştirdiği ve mutlak iyi bir insanı anlatmaya çalıştığı üzerinde durulmuştur. İnsanın duyumsadığı mutsuzluğu yalnızca sevgiyle yenebileceğini gösterme özelliği taşımasına dikkat çekilmiştir. Buna karşılık Prens Mışkin aracılığıyla Dostoyevski'nin içinde bulunduğu Rus toplumunda çıarcı, sinsi, ikiyüzlü, nesnelerin ya da arzularının kölesi olan, materyalist değerleri öncelikli kılan insanların içine dâhil ettiği böylesine dürüst ve sevgi odaklı bir insan için yaşamın ne denli zor ve budalaca olduğunu vurgulamaya çalıştığı anlaşılmıştır. Mükemmel olumlu erkek kahramanıyla yazarın öğretici bir amaca katkı sağladığı ve onu daha mükemmel hale getirmenin yollarını aradığı görülmüştür.

Dostoyevski’nin ana kadın kahramanı Nastasya Filippovna Baraşkova’nın da, tıpkı Prens Mışkin gibi, içinde bulunduğu "yozlaşmış" toplumda yaşayamadığı gözler önüne serilmeye çalışılmıştır. Romanın en başından birbirlerine yakınlı duymaları, ruhsal açıdan romanın en temiz insanları olmalarıyla ilişkilendirilmiştir. Nitekim Prens Mışkin hastalanmış ülkesini kurtarmak için yurtdışından geri döner. Nastasya Filippovna ise hasta toplumda nefes alamayacak haldedir. Dostoyevski'nin Rus toplumunun yakalandığı "yozlaşma” hastalığından kurtulmasının çaresini romanda Prens Mışkin ile timsalleştirerek sunduğu görülmüştür. Nihayetinde mükemmel insanın timsali Mışkin’in çevresindeki insanlara yabancılaşmasının ve ters düşmesinin nedeni, benimsemiş olduğu değer yargılarıyla açıklanabilmektedir.

Sonuç olarak Dostoyevski'nin "Budala" adlı eserinin hayatın ve felsefenin sorunlarını ele aldığı romanlarından biri olduğu gözlenmiştir. "Dünyayı güzellik kurtaracak" leitmotivinin özü hakkında "güzellik kurtarıcı bir güç olmaz; kurtarılmada gerekli bir güç̧ olarak görülebilir yargısına varılmıştır. Güzellik doğası gereği kırılgan ve kısmen gerçek dışı olduğu için tasarlanmıştır. Dolayısıyla yazar tarafından Prens Mışkin ve Nastasya Filippovna'nın mükemmel ve güzellik kavramlarını timsalleştirmek için doğalarına uygun bir şekilde sunuldukları gözlenmiştir. Mışkin idealin ve güzelliğin özünü kalben görme yetisine sahiptir. Onun için mükemmel ve ideal olan acı aracılığıyla ortaya çlkan hakiki güzelliktir. Söz konusu durumu daha belirgin kılmak adına Prens Mışkin ve Nastasya Filippovna karakterlerini çok boyutlu, yüzeyselden daha derin bir yapıya doğru uzanan bir okuma örneğinde sunmaya gayret edilmiştir. Bu noktada Dostoyevski’nin güzellik kavramına bakışının tek yönlü olmadığı anlaşılmıştır. 


\section{Kaynakça}

Akimova, N. V. (2021). “Kompozitsiya obrazov glavnıh geroyev v romanah F.M. Dostoyevskogo ‘'̇diot' i 'Besı'”. Obrazovaniye i kul'turnoye prostranstvo. No. 2. 44-51.

Battalova, A. N. (2011). "Roman F. M. Dostoyevskogo "İdiot” v avtobiografiçeskom kontekste”. Vestnik Çelyabinskogo gasudarstvennogo universiteta. No: 20 (235). Filologiya. İskusstvovedeniye. Vipusk 56. 31-34.

Bogdanova, O. A. (2007). “ 'Obraz çistoy krasotı' v romane F. M. Dostoyevskogo 'İdiot' ”. Problemı filologii, kul'turologii i iskusstvovedeniya, 101-104.

Dostoyevski, F. M. (2008). Budala. (Çev. Mazlum Beyhan). 6. Baskı, İstanbul: İletişim Yayınları.

Dostoyevski, F. M. (2014). Dostoyevski Mektuplar. (Çev. Hüseyin Kandemir). Konya: Çizgi Kitabevi.

Euripides. (2014). Medea. (Çev. Ari Çokona). İstanbul: Türkiye İş Bankası Kültür Yayınları.

Günay, D. (2003). Metin Bilgisi. İstanbul: Multilingual Yayınevi.

Kandemir, H. (2014). Dostoyevski Biyografi. Konya: Çizgi Kitabevi.

Karataş, N. C. (2018). Rus Düşüncesi Bağlamında F. M. Dostoyevski’de Yabancılaşma Olgusu. Doktora Tezi. İstanbul Üniversitesi Sosyal Bilimler Enstitüsü, İstanbul.

Kartal, J. (2015). F. M. Dostoyevski’nin Uzun Öykü Sanatı. Yüksek Lisans Tezi. Gazi Üniversitesi Sosyal Bilimler Enstitüsü, Ankara.

Kopılova, A. A. \& Buryanova, G.B. (2021). Jenskiye obrazı v romane F. M. Dostoyevskogo "İdiot”. V sbornike: Tvorçestvo F.M. Dostoyevskogo v neproşedşem vremeni Rossii. Materialı Vserossiykoy nauçnoy konferentsii. Lipetsk. 50-55.

Köksal, M. H. (2017). Dünya Sinemasında F. M. Dostoyevskïnin Budala Adlı Eserinin Uyarlamaları. Yüksek Lisans Tezi. İstanbul Üniversitesi Sosyal Bilimler Enstitüsü, İstanbul.

Kuznetsova, Ye. V. (2015). “Neodnoznaçnost' obraza Nastas'i Filippovnı v romane F. M. Dostoyevskogo 'İdiot' ”. Nauka i souremennost. No: 35. 149-153.

Manukyan, G .V. (2020). "Leksema krasota v romane F.M. Dostoyevskogo 'İdiot' ". Vestnik Udmurtskogo Universiteta, T. 30. Vipusk 5 751-755.

Nilova, A. Yu. (2020). Antiçnıye traditsii v romane Dostoyeuskogo "İdiot” (Medeya kak istoçnik obraza Nastas'i Filippounı). V knige: Paradigmı kul'turnoy pamyati i konstantı natsionalnoy identiçnosti. Kollektivnaya monografiya. Nijniy Novgorod. 204-209.

Ögel, B. (2017). XIX. YY. Rus Edebiyatında F.M. Dostoyevski Eleştirisi. Yüksek Lisans Tezi. Ağrı İbrahim Çeçen Üniversitesi Sosyal Bilimler Enstitüsü, Ağrı.

Petrova, A. A. (2016). Krasota $v$ Sodome? (K traktovke obraza Nastasï Filippovn v romane F. M. Dostoyevskogo "İdiot". V sbornike: Aktual'nıye problemı sovremennoy gumanitarnoy nauki. Materialı III mejdunarodnoy nauçno-praktiçeskoy konferentsii. 22-26.

Purevdorj, A. (2017). F. M. Dostoyevskïnin Romanlarındaki Karakter Çerçevelerinin İncelenmesi. Doktora Tezi. Ankara Üniversitesi Eğitim Bilimleri Enstitüsü, Ankara.

Sarıbaş, E. (2010). Wilhelm Friedrich Nietzsche ve Fyodor Mihailoviç Dostoyevski'de İnsan Problemi. Yüksek Lisans Tezi. Gazi Üniversitesi Sosyal Bilimler Enstitüsü, Ankara.

Şahin, D. (2016). Dostoyevski’de Tanrı ve Din. Yüksek Lisans Tezi. Uludağ Üniversitesi Sosyal Bilimler Enstitüsü. Bursa.

Şener, L. (2018). Mektuplar ve Süreli Yayınlarda F. Dostoyevski”nin "Budala" Roman Hakkinda Yer Alan Görüssler (1868-1881). 1. Uluslararası Eğitim ve Sosyal Bilimlerde Yeni Ufuklar Kongresi (ICES-2018), 143-150.

Şetinin, R. B. (2007). “Razvitiye obrazov Mrsskina i Rogojina v romane F. M. Dostoyevskogo 'İdiot'”. Vestnik Tom. Gos. Universiteta. No: 304. 
Toiçkina, A. V. (2001). Otsenoçnoye pole obraza knyazya Mışkina v romane F. M. Dostoyevskogo "İdiot" (Reçevoy Aspekt). 206-229.

Troyat, H. (2000). Dostoyevski. (Çev. Leyla Gürsel). İstanbul: Cem Yayınevi.

Tumarkina, L. V. Krasota spaset li mir? Filosofskiye osnovaniya prekrasnogo v etike F. M. Dostoyevskogo i N.F. Fedorova (K 150 letiyu vihoda v svet romana F. M. Dostoyevskogo "İdiot). Filosofiya i obşestuo. No: 1. 111-126.

Ülger, E. (2013). "Platon’un Sanat Kuramının Düşünsel Evrimi”. FLSF Felsefe ve Sosyal Bilimler Dergisi. 15-28.

Sapel'nikov, A. V. (2005). “İmena Geroyev romana F. M. Dostoyevskogo 'İdiot' ". Vestnik Novgorodskogo gosudarstvennogo universiteta. No: 33. 69-72. 